DOI: 10.17117/na.2017.01.03.339

Поступила (Received): 17.01.2017

\title{
Сазонова Н.В.
}

\section{К вопросу о воздействии автомобильного транспорта на окружающую среду города Белгорода}

\author{
Sazonova N.V. \\ To a question of impact of the motor transport \\ on environment of Belgorod city
}

Автор в данной статье рассматривает специфику загрязнения окружающей среды города Белгорода автомобильным транспортом. Отмечено, что наиболее актуальной проблемой загрязнения окружающей среды автотранспортом являются выбросы в атмосферный воздух

Ключевые слова: автомобильный транспорт, загрязнение окружающей среды, город Белгород

\section{Сазонова Нина Васильевна}

Кандидат географических наук, доцент

Белгородский государственный национальный исследовательский университет

г. Белгород, ул. Победы, 85
In this article the author is considering the specifics of environmental pollution of the city of Belgorod by the motor transport. It is noted that the most actual problem of environmental pollution by motor transport are emissions in atmospheric air

Key words: motor transport, environmental pollution, Belgorod city

\author{
Sazonova Nina Vasilievna \\ Candidate of Geographical Sciences, Associate \\ Professor \\ Belgorod state national research university \\ Belgorod, Pobeda st., 85
}

Одной из наиболее острых проблем, связанных с загрязнением окружающей среды г. Белгорода, как и других городов России, является автомобильный транспорт - крупнейший источник загрязнения атмосферы города - его доля составляет около $80 \%$.

Влияние транспорта на экологическую ситуацию города обуславливается не только загрязнением атмосферного воздуха выхлопными газами, но также загрязнением водного бассейна (стоки с автомобильных моек, стоянок, гаражей, АЗС и др.) и почвы (отходы, загрязненные нефтепродуктами, сажевые частицы шин от истирания на дорогах и др.). Наиболее актуальной проблемой загрязнения окружающей среды автотранспортом являются выбросы в атмосферный воздух. Удельный вес выбросов автотранспорта в общем выбросе в атмосферу и объемы выбросов автотранспорта представлены на рис.1.

Контроль за загрязнением атмосферного воздуха в области осуществляется областным Центром по мониторингу загрязнения атмосферы Старооскольской комплексной лабораторией мониторинга окружающей среды на 8 стационарных постах в гг. Белгороде, Губкине, Старом Осколе. 


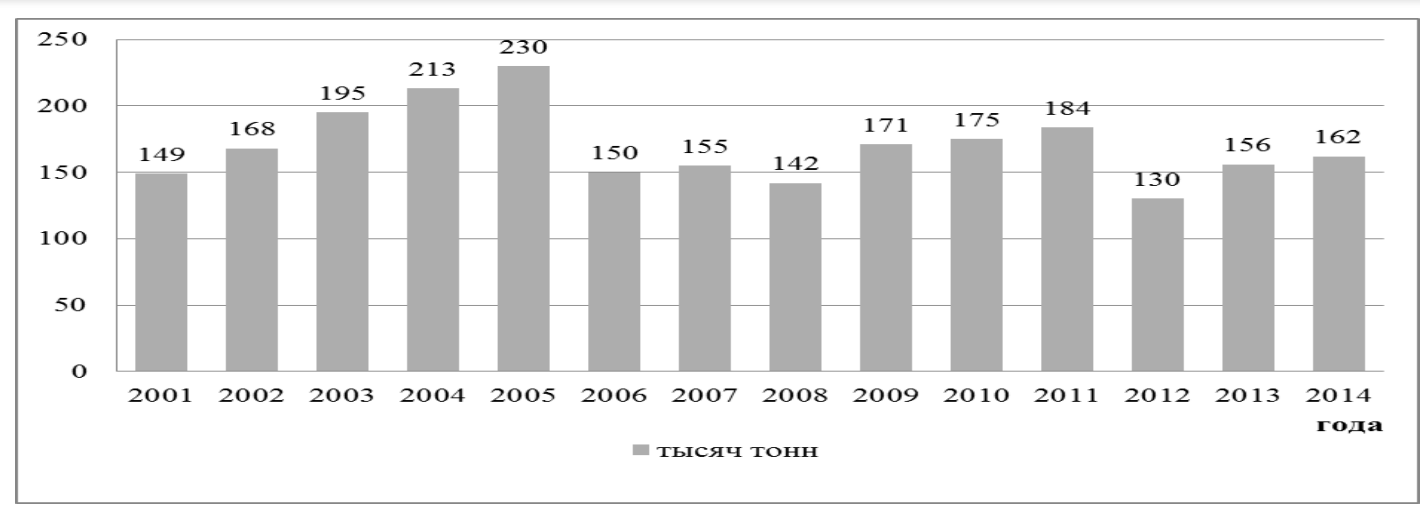

Pис. 1. Динамика выбросов загрязняющих атмосферу веществ от автомобильного транспорта (тысяч тонн)

По данным контроля в г. Белгороде за последние пять лет, имеется тенденция к снижению уровня загрязнения атмосферы пылью, серы диоксидом, аммиаком и серной кислотой, повышению концентраций азота диоксида, азота оксида, формальдегида и водорода хлористого; отмечается стабилизация содержания фенола и окиси углерода. Следует подчеркнуть, что в 2014 году среднегодовая концентрация формальдегида превысила допустимые нормы и составила 1,33 ПДКсс, отмечались превышения максимально разовых концентраций пыли до 1,2 ПДК и углерода оксида до 1,4 ПДК.

В целом, положение дел с состоянием воздушного бассейна в области не следует расценивать как благополучное. Проводимые технологические, санитарно-технические, планировочные мероприятия в настоящее время не позволяют существенно снизить уровни загрязнения атмосферы в основных городах области, исключить прирост валовых выбросов от стационарных источников в связи с активизацией основной деятельности промышленных предприятий.

Объем выбросов загрязняющих веществ в атмосферный воздух от автомобильного транспорта превышает таковой от всех других источников, особенно в крупных городах. Данное обстоятельство отрицательно сказывается на здоровье городского населения [5, с. 56]. Для Белгородской области экологические проблемы автомобильного транспорта стали особенно актуальными в последнее время. В 2014 г. автомобильный парк Белгородской области составил 568,2 тыс. машин, в том числе 8,4 тыс. автобусов, 70,9 тыс. грузовых и 488,9 тыс. легковых автомобилей (рис.2) [1, с. 150; 3, с. 167].

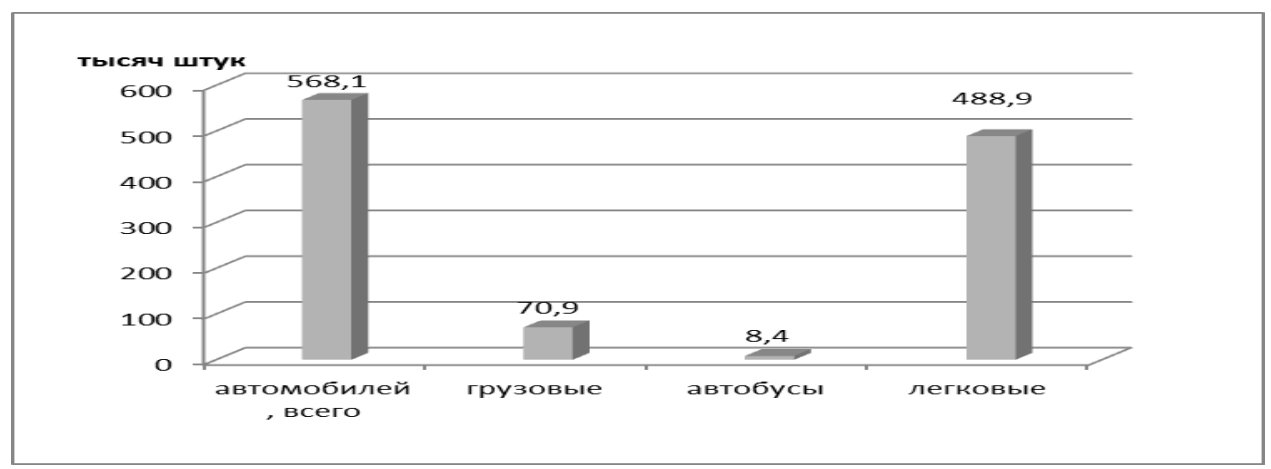

Рис. 2. Наличие подвижного состава автомобильного транспорта Белгородской области в 2014 г. (тыс. штук) 
Загрязнение воздуха представляет серьезную угрозу здоровью населения, способствует снижению качества жизни. Воздействие токсичных веществ, загрязняющих воздух, вызывает такие заболевания как: рак, лейкемия, астма, эндокринные заболевания, респираторные заболевания, различные виды аллергии, сердечно-сосудистые заболевания, болезни печени, болезни желчного пузыря, болезни органов чувств.

Через выхлопные трубы автомобилей в атмосферу выбрасывается более двухсот химических веществ. Самое токсичное воздействие на живые организмы оказывают соединения тяжелых металлов, среди них наиболее опасен свинец, накапливающийся в радиусе 100-200 м. от дороги.

Транспортный комплекс - крупнейший источник загрязнения атмосферы города - его доля составляет около 80\% [5, с. 124].

Известно, что в отработанных газах автомобилей присутствует около 200 видов вредных компонентов, 94,1\% из которых - высокотоксичные, канцерогенные вещества, и сейчас уровень загрязнения атмосферы в городе определяется как высокий по концентрации наиболее токсичного бенз(а)пирена, выделяемого автотранспортными средствами.

В городах Белгородской области, среди наиболее распространенных выбросов в атмосферу веществ от автомобильного транспорта, преобладают выбросы оксидов углерода, азота, азота и углеводороды (табл.1).

Таблица 1. Выбросы наиболее загрязняющих атмосферу веществ автомобильным транспортом в 2014 году (тыс. тонн)

\begin{tabular}{|l|c|c|c|c|c|c|c|c|}
\hline & \multirow{2}{*}{ Всего } & \multicolumn{7}{|c|}{ Из них: загрязняющих веществ } \\
\cline { 3 - 9 } & $\begin{array}{c}\text { диок- } \\
\text { сид } \\
\text { серы }\end{array}$ & $\begin{array}{c}\text { ок- } \\
\text { сиды } \\
\text { азота }\end{array}$ & ЛОС & $\begin{array}{c}\text { оксид уг- } \\
\text { лерода }\end{array}$ & сажа & $\begin{array}{c}\text { ам- } \\
\text { миак }\end{array}$ & метан \\
\hline $\begin{array}{l}\text { Белгородская } \\
\text { обл, в том } \\
\text { числе }\end{array}$ & 161,6 & 0,9 & 18,1 & 16,6 & 124,6 & 0,3 & 0,4 & 0,7 \\
\hline г. Алексеевка & 5,4 & 0,03 & 0,5 & 0,6 & 4,3 & 0,01 & 0,01 & 0,02 \\
\hline г. Белгород & 31,0 & 0,2 & 2,8 & 3,2 & 24,6 & 0,06 & 0,06 & 0,1 \\
\hline $\begin{array}{l}\text { г.Старый } \\
\text { Оскол }\end{array}$ & 18,0 & 0,09 & 1,6 & 1,9 & 14,3 & 0,03 & 0,04 & 0,1 \\
\hline г. Губкин & 6,0 & 0,03 & 0,5 & 0,6 & 4,8 & 0,01 & 0,01 & 0,03 \\
\hline г. Шебекино & 5,7 & 0,03 & 0,5 & 0,6 & 4,6 & 0,01 & 0,01 & 0,03 \\
\hline
\end{tabular}

С целью минимизации негативного воздействия на окружающую среду выбросов автотранспорта, осуществляется ремонт, регулировка, техническое обслуживание систем и агрегатов, влияющих на выброс вредных веществ, организован контроль за содержанием загрязняющих веществ в выхлопных газах [2, c. $8 ; 4$, c. 211].

В заключение необходимо отметить, что одной из актуальных задач в решении эколого-транспортных проблем является сохранение и развитие системы защиты окружающей среды, соблюдение международных стандартов качественных характеристик топлива и норм выброса токсичных веществ. 


\section{Список используемых источников:}

1. Белгородская область в цифрах 2015. Белгородстат. 2015. 278 с.

2. Павлов К.В., Сазонова Н.В., Соловьев А.Б. Трудовой потенщиал Белгородской области: современное состояние и основные направления повышения эффективности управления // Региональная экономика: теория и практика. 2008. № 29. С. 7-13.

3. Сазонова Н.В. Современные проблемы развития автомобильного транспорта Белгородской области в условиях геоэкономической и политической нестабильности / Муниципальные образования современных регионов: проблемы исследования, развития и управления в условиях геоэкономической и политической нестабильности: материалы Первой международной научно-практической конференции. 14-15 апреля 2016. Воронежский государственный университет / под общ. ред. проф. Н.В.Яковенко. Воронеж: Издательско-полиграфический центр «Научная книга», 2016. С 167-171.

4. Соловьев А.Б., Полякова Т.А., Богат Д.В., Сазонова Н.В. Социально-экологическая оценка качества жилой застройки г. Белгорода // Проблемы региональной экологии. 2013. № 4. С. 211-214.

5. Состояние транспортного комплекса Белгородской области в 2014г.: Стат. сб./ Белгородстат. 2015. $278 \mathrm{c}$.

(C) 2017, Сазонова Н.В.

К вопросу о воздействии автомобильного транспорта на окружающую среду города Белгорода
(C) 2017, Sazonova N.V.

To a question of impact of the motor transport on environment of Belgorod city 